\title{
REDESAIN SISTEM ELEKTRIKAL STADION CITARUM (BAGIAN SISTEM INSTALASI LISTRIK)
}

\author{
Nungky Prameswari ${ }^{*}$, Karnoto, dan Hermawan \\ Departemen Teknik Elektro, Universitas Diponegoro \\ J1. Prof. Sudharto, SH, Kampus UNDIP Tembalang, Semarang 50275, Indonesia \\ ${ }^{*}$ E-mail:nungkyprameswari24@gmail.com
}

\begin{abstract}
Abstrak
Stadion Citarum sebagai salah satu stadion di Kota Semarang sejak tahun 2007 sudah tidak dapat mengadakan eventevent pertandingan sepakbola ketika malam hari. Hal ini disebabkan oleh keterbatasan pencahayaan lapangan dan sistem instalasi kelistrikan didalamnya yang dianggap kurang dari standar yang diizinkan yaitu Standart Nasional Indonesia (SNI) dan Persyaratan Umum Instalasi Listrik (PUIL) 2011. Melihat hal tersebut, penulis akan merancang sebuah desain perbaikan instalasi listrik Stadion Citarum Kota Semarang yang disesuaikan dengan Standart Nasional Indonesia (SNI) dan Persyaratan Umum Instalasi Listrik (PUIL) 2011 dengan menggunakan software Ecodial 4.8. Beberapa parameter yang akan dihitung didalamnya meliputi luas penampang penghantar, arus hubung singkat, jatuh tegangan, serta kapasitor bank yang diperlukan. Hasil dari simulasi dan perhitungan menunjukan bahwa rancangan yang dibuat sudah sesuai dengan standart, terbukti dengan hasil perhitungan luas penampang penghantar dari Ecodial 4.8 dan manual hanya berbeda $\pm 1 \%$, dan jatuh tegangan dari kedua perhitungan ini sudah dibawah $4 \%$. Disamping luas penampang penghantar, dari parameter perhitungan lainnya seperti arus hubung singkat, jatuh tegangan dan kebutuhan kapasitor bank, keduanya sudah memperlihatkan hasil yang memiliki perbedaan $\pm 1 \%$.
\end{abstract}

Kata Kunci: desain, instalasi listrik, ECODIAL 4.8

\begin{abstract}
Citarum Stadium as one of the stadiums in Semarang City since 2007 has been unable to hold football match events at night. This is due to the limitations of field lighting and electrical installation systems in it which are considered to be less than the permissible standards, namely the Standart Nasional Indonesia (SNI) and the Persyaratan Umum Instalasi Listrik (PUIL) 2011. Seeing this, the author will design a design for repairing the electrical installation of the Citarum Stadium which is adjusted to the Standart Nasional Indonesia (SNI) and Persyaratan Umum Instalasi Listrik (PUIL) 2011 using Ecodial 4.8 software. Some parameters that will be calculated in it include cross-sectional area, short-circuit current, voltage drop, and a capacitor bank that is needed. The results of the simulation and calculation show that the design made is in accordance with the standard, as evidenced by the results of the calculation of the cross-sectional area of the Ecodial 4.8 and manual only $\pm 1 \%$, and the voltage drop from these two calculations is already below $4 \%$. Besides the cross-sectional area, from other calculation parameters such as short circuit current, voltage drop and bank capacitor requirements, both have shown results that have a difference of $\pm 1 \%$.
\end{abstract}

Keywords: design, electrical installation, ECODIAL 4.8.

\section{Pendahuluan}

Sarana olahraga diperlukan masyarakat untuk menyelenggarakan perhelatan atau kompetisi tertentu. Salah satu cabang olahraga yang paling digemari masyarakat adalah sepakbola. Semarang sebagai ibukota Provinsi Jawa Tengah memiliki beberapa stadion sepakbola, salah satunya Stadion Citarum.

Stadion Citarum sudah berdiri sejak tahun 1983, stadion dengan luas 9348 meter persegi ini memiliki 4 tribun dengan kapasitas sekitar 3868 penonton. Sejak tahun 2007, pertandingan sepakbola yang dilaksanakan pada malam hari tidak mampu lagi diselenggarakan di Stadion
Citarum karena keterbatasan ketersediaan penerangan pada malam hari yang memenuhi standar. Kondisi ini mengakibatkan Stadion Citarum tidak mampu menyelenggarakan event-event besar. Sistem kelistrikan tidak dapat dipisahkan dari keberadaan suatu bangunan baik perkantoran, industri, rumah sakit, gelanggang olahraga dan lain-lain. Gedung yang megah dengan arsitektur yang indah belum menjamin terciptanya suasana nyaman bila tidak didukung oleh instalasi listrik yang baik. Risiko kebakaran, arus bocor, dan suasana tidak nyaman akan terjadi jika instalasi listriknya tidak mengutamakan keamanan [2]. Melihat hal tersebut, penulis yang akan merancang sebuah desain perbaikan 
instalasi listrik Stadion Citarum Kota Semarang yang sesuai dengan Standart Nasional Indonesia (SNI) dan Persyaratan Umum Instalasi Listrik (PUIL) menggunakan Ecodial 4.8 .Metode simulasi dan perhitungan digunakan sebagai pendekatan untuk menentukan spesifikasi komponen - komponen yang akan digunakan dengan mengacu pada PUIL 2011 dan Undang - undang ketenagalistrikan tahun 2002 [3]. Analisa yang digunakan untuk merancang instalasi listrik Stadion Citarum Kota Semarang menggunakan software Ecodial 4.8. Ecodial 4.8 merupakan software yang dibuat oleh perusahaan Schneider untuk membantu menentukan kapasitas kebutuhan dari sistem distribusi tenaga listrik, menghitung dan menentukan spesifikasi teknis yang sesuai, aman dan handal.

Dalam pembuatan tugas akhir ini, pembahasan dibatasi pada:

1. Pemodelan perancangan diagram satu garis Stadion Citarum Semarang menggunakan software Ecodial 4.8

2. Perancangan diutamakan pada masalah teknis saja, tidak membahas biaya dan sisi mekanikal

3. Tinjauan perancangan instalasi listrik mengacu pada Standar Nasional Indonesia PUIL 2011

4. Perhitungan hanya pada sisi instalasi listrik yang terkait dengan beban kebutuhan listrik dan bukan pada peralatan yang digunakan atau spesifikasi yang digunakan.

5. Tidak membahas penghantar netral dan penghantar proteksi (PE) , hanya membahas persyaratan umum penghantar netral dan proteksi

\section{Metode}

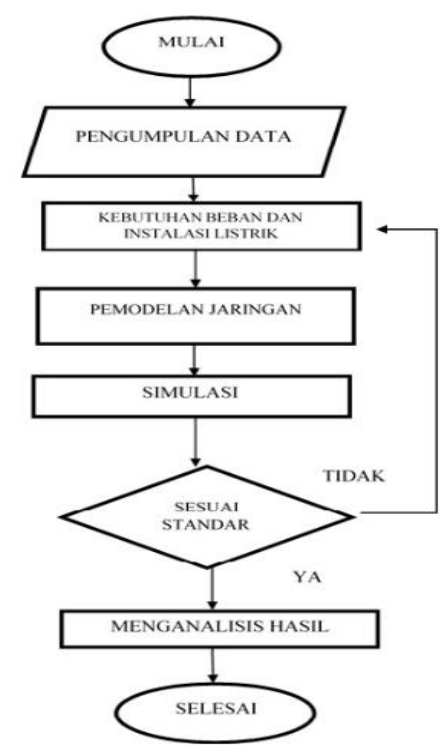

Gambar 1. Diagram alir penelitian

\subsection{Pengumpulan Data}

Tahap pengumpulan data dilakukan dengan pengumpulan data secara langsung melalui pengukuran luas tiap-tiap ruangan untuk mendapatkan gambar denah dari Stadion Citarum Semarang. Berikut ini adalah pembagian beban tiap lantainya :

Tabel 1. Total Beban LVMDP.

\begin{tabular}{ll}
\hline SUMBER & BEBAN (WATT) \\
\hline LVMDP KE SDP LANTAI 1 & 66618 \\
LVMDP KE SDP LANTAI 2 & 30492 \\
LVMDP KE SDP LANTAI 3 & 4634 \\
LVMDP KE SDP Penerangan Lapangan & 252000 \\
LVMDP KE SDP Pompa & 51000 \\
\hline TOTAL & 404744 \\
\hline
\end{tabular}

\subsection{Kebutuhan Beban dan Instalasi Listrik}

Untuk mendapatkan perhitungan beban maka harus dibuat denah instalasi perencanaan untuk instalasi beban yang akan digunakan . Pada Stadion Citarum Semarang memiliki 5 bagian panel sekunder atau SDP ( secondary distribution panel ) beban dengan rincian sebagai sebagai berikut :

1. SDP Lantai 1

2. SDP Lantai 2

3. SDP Lantai 3

4. SDP Penerangan Lapangan

5. SDP Pompa

Dari ke lima pembagian diatas terbagi atas 3 mode sistem kelistrikan yang memiliki fungsi berbeda sesuai dengan keadaannya yaitu :
1. Normal
2. PLN off
3. Emergency

Tabel 2. Perkiraan Kebutuhan Beban Stadion Citarum

\begin{tabular}{lcc}
\hline \multicolumn{1}{c}{ SUMBER } & $\begin{array}{c}\text { Panjang Kabel } \\
(\mathrm{m})\end{array}$ & Beban (Watt) \\
\hline LVMDP KE SDP LANTAI 1 & 1 & 66618 \\
LVMDP KE SDP LANTAI 2 & 5 & 30492 \\
LVMDP KE SDP LANTAI 3 & 10 & 4634 \\
LVMDP KE SDP Penerangan & & \\
Lapangan & 60 & 252000 \\
LVMDP KE SDP Pompa & 60 & 51000 \\
1. SDP LANTAI 1 & & \\
PP/LP 1.1 & 2 & 10848 \\
PPILP 1.2 & 2 & 4590 \\
AIR CONDITIONER 1.1 & 2 & 41520 \\
AIR CONDITIONER 1.2 & 2 & 9660 \\
2. SDP LANTAI 2 & & \\
PP/LP 2.1 & 20 & 2512 \\
PPILP 2.2 & 2 & 3760 \\
AIR CONDITIONER 2.1 & 2 & 24220 \\
3. SDP LANTAI 3 & & \\
Penerangan + AC Lantai 3 & 10 & 4634 \\
4. SDP Penerangan Lapangan & & \\
Penerangan Lapangan Tiang 1 & 2 & 63000 \\
Penerangan Lapangan Tiang 2 & 70 & 63000 \\
Penerangan Lapangan Tiang 3 & 170 & 63000 \\
Penerangan Lapangan Tiang 4 & 70 & 63000 \\
5. SDP Pompa & & \\
Pompa Air Bersih 1 & 2 & 3000 \\
Pompa Air Bersih 2 & 100 & 4000 \\
Pompa Hydrant & 20 & \\
\hline
\end{tabular}




\subsection{Pemodelan Jaringan}

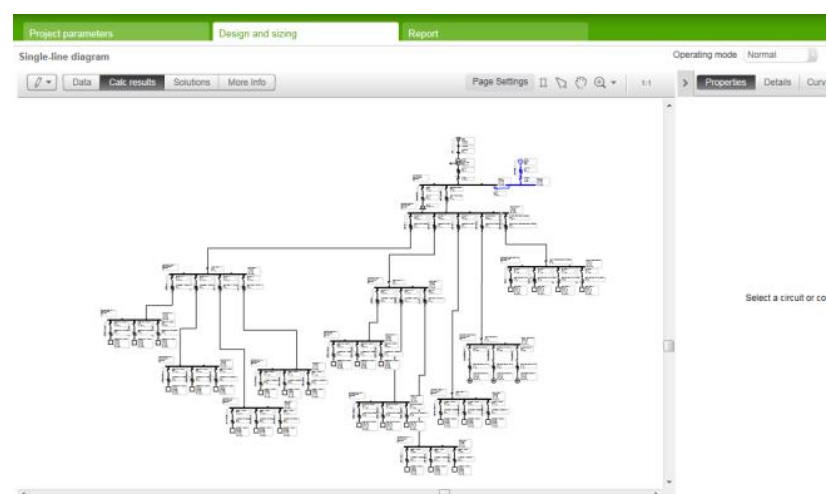

Gambar 2. Diagram garis tunggal pada Ecodial 4.8

\section{Hasil dan Analisis}

\subsection{Hasil Simulasi Ecodial 4.8}

Dari single line diagram yang dibuat pada ecodial, selanjutnya akan disimulasikan mendapatkan hasil perhitungan sebagai berikut :

Tabel 3. Perhitungan luas penghantar dan jatuh tegangan menurut Ecodial 4.8

\begin{tabular}{|c|c|c|c|c|}
\hline \multirow{2}{*}{ Sumber } & \multicolumn{3}{|c|}{ Luas Penghantar } & \multirow[b]{2}{*}{$\Delta \mathrm{U}(\%)$} \\
\hline & Fasa & Netral & PE & \\
\hline TRAFO KE ATS & $3 \times 400$ & $3 \times 400$ & $2 \times 300$ & 0,072 \\
\hline ATS KE LVMDP & $3 \times 300$ & $3 \times 300$ & $2 \times 240$ & 0,24 \\
\hline PANEL SDP & & & & 0 \\
\hline LVMDP KE SDP LANTAI 1 & 50 & 50 & 25 & 0,414 \\
\hline LVMDP KE SDP LANTAI 2 & 50 & 50 & 25 & 0,417 \\
\hline LVMDP KE SDP LANTAI 3 & 2,5 & 2,5 & 4 & 0,541 \\
\hline \multicolumn{5}{|l|}{ LVMDP KE SDP Penerangan } \\
\hline Lapangan & 300 & 300 & 150 & 1,098 \\
\hline LVMDP KE SDP Pompa & 70 & & 35 & 1,39 \\
\hline 1. SDP LANTAI 1 & & & & 0 \\
\hline PP/LP 1.1 & 10 & 10 & 10 & 0,205 \\
\hline PP/LP 1.2 & 1,5 & 1,5 & 4 & 0,263 \\
\hline AIR CONDITIONER 1.1 & 35 & 50 & 25 & 0,174 \\
\hline AIR CONDITIONER 1.2 & 4 & 4 & 4 & 0,205 \\
\hline 2. SDP LANTAI 2 & & & & 0 \\
\hline PP/LP 2.1 & 1,5 & 1,5 & 4 & 0,69 \\
\hline PP/LP 2.2 & 1,5 & 1,5 & 4 & 0,255 \\
\hline AIR CONDITIONER 2.1 & 25 & 16 & 16 & 0,218 \\
\hline 3. SDP LANTAI 3 & & & & 0 \\
\hline Penerangan + AC Lantai 3 & 2,5 & 2,5 & 4 & 0,541 \\
\hline 4. SDP Penerangan Lapangan & & & & 0 \\
\hline Penerangan Lapangan Tiang 1 & 70 & 70 & 35 & 1,18 \\
\hline Penerangan Lapangan Tiang 2 & 95 & 95 & 50 & 1,95 \\
\hline Penerangan Lapangan Tiang 3 & 240 & 240 & 120 & 2,14 \\
\hline Penerangan Lapangan Tiang 4 & 95 & 95 & 50 & 1,95 \\
\hline 5. SDP Pompa & & & & 0 \\
\hline Pompa Air Bersih 1 & 1,5 & & 4 & 0,925 \\
\hline Pompa Air Bersih 2 & 6 & & 6 & 1,71 \\
\hline Pompa Hydrant & 35 & & 16 & 1,27 \\
\hline
\end{tabular}

Untuk beban pada trafo dan besarnya kapasitor menurut ecodial adalah sebagai berikut :
1. Total beban terpasang
: $404632 \mathrm{VA}$
2. Besar kapasitor bank
$225 \mathrm{kVar}$
3. Dipilih Trafo
: $630 \mathrm{Kva}$

Tabel 4. Perhitungan Pengaman dan Arus Hubung Singkat Menurut Ecodial 4.8

\begin{tabular}{|c|c|c|c|c|}
\hline Sumber & $\begin{array}{l}\text { Circuit } \\
\text { Breaker }\end{array}$ & $\begin{array}{l}\text { Rating } \\
\text { MCB } \\
\text { (A) }\end{array}$ & $\begin{array}{l}\text { Isc(k } \\
\text { A) }\end{array}$ & $\begin{array}{l}\text { Cap. } \\
\text { Breakin } \\
\text { g(kA) }\end{array}$ \\
\hline TRAFO KE ATS & NT16H2 & 1600 & 21,7 & 50 \\
\hline $\begin{array}{l}\text { ATS KE LVMDP } \\
\text { PANEL SDP } \\
\text { LVMDP KE SDP }\end{array}$ & NT08H2 & 800 & 21,4 & 50 \\
\hline $\begin{array}{l}\text { LANTAI } 1 \\
\text { LVMDP KE SDP }\end{array}$ & NSX100N & 100 & 21 & 50 \\
\hline $\begin{array}{l}\text { LANTAI } 2 \\
\text { LVMDP KE SDP }\end{array}$ & NSX100N & 100 & 19,6 & 50 \\
\hline $\begin{array}{l}\text { LANTAI } 3 \\
\text { LVMDP KE SDP }\end{array}$ & NG125N & 16 & 6,05 & 25 \\
\hline $\begin{array}{l}\text { Penerangan Lapangan } \\
\text { LVMDP KE SDP }\end{array}$ & NSX400F & 400 & 13,9 & 36 \\
\hline $\begin{array}{l}\text { Pompa } \\
\text { 1. SDP LANTAI } 1\end{array}$ & NSX250N & 250 & 10 & 50 \\
\hline PP/LP 1.1 & NSX100B & 100 & 18,4 & 25 \\
\hline $\begin{array}{l}\text { PP/LP } 1.2 \\
\text { AIR CONDITIONER }\end{array}$ & iC60L & 10 & 8,29 & 25 \\
\hline $\begin{array}{l}1.1 \\
\text { AIR CONDITIONER }\end{array}$ & NSX160F & 160 & 20,1 & 36 \\
\hline $\begin{array}{l}1.2 \\
2 . \text { SDP LANTAI } 2\end{array}$ & iC60L & 20 & 14,6 & 25 \\
\hline PP/LP 2.1 & iC60L & 6 & 1,01 & 25 \\
\hline $\begin{array}{l}\text { PP/LP } 2.2 \\
\text { AIR CONDITIONER }\end{array}$ & iC60L & 10 & 7,9 & 25 \\
\hline $\begin{array}{l}2.1 \\
\text { 3. SDP LANTAI } 3 \\
\text { Penerangan + AC }\end{array}$ & NSX100B & 100 & 18,5 & 25 \\
\hline $\begin{array}{l}\text { Lantai } 3 \\
\text { 4. SDP Penerangan } \\
\text { Lapangan } \\
\text { Penerangan Lapangan }\end{array}$ & NG125N & 16 & 6,05 & 25 \\
\hline $\begin{array}{l}\text { Tiang } 1 \\
\text { Penerangan Lapangan }\end{array}$ & NSX160B & 160 & 13,7 & 25 \\
\hline $\begin{array}{l}\text { Tiang } 2 \\
\text { Penerangan Lapangan }\end{array}$ & NSX160B & 160 & 8,2 & 25 \\
\hline $\begin{array}{l}\text { Tiang } 3 \\
\text { Penerangan Lapangan }\end{array}$ & NSX160B & 160 & 6,7 & 25 \\
\hline $\begin{array}{l}\text { Tiang } 4 \\
\text { 5. SDP Pompa }\end{array}$ & NSX160B & 160 & 8,2 & 25 \\
\hline Pompa Air Bersih 1 & GV2ME & 10 & 5,41 & 150 \\
\hline Pompa Air Bersih 2 & GV2ME & 10 & 5,41 & 150 \\
\hline Pompa Hydrant & NSX100F & 100 & 7,24 & 36 \\
\hline
\end{tabular}

\subsection{Hasil Perhitungan Manual}

\subsubsection{Perhitungan Luas Penampang Kabel}

Contoh perhitungan penghantar SDP Lantai 1 ke SSDP PP/LP 1.2 :

Kabel Fasa : Karena beban PP/LP 1.2 sebesar 4590 W maka sesuai dengan persamaan (2.1') dan sesuai PUIL 2011 untuk $\cos \varphi$ antara $0,8 \sim 0,9$.

$$
\begin{aligned}
& \text { - Dengan asumsi } \cos \varphi=0,85 \\
& \text { - } I=\frac{4590}{\sqrt{3} \times 400 \times 0,85} \\
& \text { - } \mathrm{I}=7,79 \text { Ampere }
\end{aligned}
$$

Arus nominal pada PP/LP 1.2 sebesar 7,79 Ampere, maka sesuai persamaan (2.2) diperoleh :

- $\mathrm{KHA}=1.25 \times 7,79$ ampere

- KHA = 9,742 ampere

Sesuai dengan tabel lampiran maka diperoleh ukuran penghantar NYY $1,5 \mathrm{~mm}^{2}$ dan dipilih pemutus sirkit dengan arus pengenal 10 Ampere 
Perhitungan penghantar Netral :

Pada ukuran kabel fasa PP/LP 1.2 sebesar $1,5 \mathrm{~mm}^{2}$ maka sesuai persamaan (2.3) diperoleh :

- $\mathrm{N}=1 \times 1,5 \mathrm{~mm}^{2}$

- $\mathrm{N}=1,5 \mathrm{~mm}^{2}$

Untuk perhitungan manual ini digunakan standart sesuai yang digunakan Ecodial 4.8

Perhitungan penghantar PE :

Pada ukuran kabel fasa PP/LP 1.2 sebesar $1,5 \mathrm{~mm}^{2}$, maka untuk pemilihan kabel PE sesuai dengan tabel 2.1 diperoleh :

$$
\begin{aligned}
& \text { - } \quad \mathrm{PE}=1,5 \mathrm{~mm}^{2}: 2 \\
& \text { - } \quad \mathrm{PE}=0,75 \mathrm{~mm}^{2}
\end{aligned}
$$

karena tidak ada kabel ukuran $0,75 \mathrm{~mm}^{2}$ maka dipilih ukuran terdekat diatasnya yaitu $1,5 \mathrm{~mm}^{2}$ atau bisa juga dengan menggunakan kabel $4 \mathrm{~mm}^{2}$.

\begin{tabular}{|c|c|c|c|c|c|}
\hline \multirow[t]{2}{*}{ SUMBER } & \multirow{2}{*}{$\begin{array}{c}\text { In } \\
\text { (Ampere) }\end{array}$} & \multirow{2}{*}{$\begin{array}{c}\text { KHA } \\
\text { (Amper } \\
\text { e) }\end{array}$} & \multicolumn{3}{|c|}{$\begin{array}{l}\text { Luas Penampang } \\
\text { Penghantar }\left(\mathrm{mm}^{2}\right)\end{array}$} \\
\hline & & & Fasa & Netral & $\mathrm{PE}$ \\
\hline TRAFO KE ATS & 687,2913 & 1116,8 & $2 \times 400$ & $2 \times 400$ & 300 \\
\hline $\begin{array}{l}\text { ATS KE LVMDP } \\
\text { PANEL SDP } \\
\text { LVMDP KE SDP }\end{array}$ & 687,2913 & 1116,8 & $2 \times 300$ & $2 \times 300$ & 240 \\
\hline $\begin{array}{l}\text { LANTAI } 1 \\
\text { LVMDP KE SDP }\end{array}$ & 113,1233 & 183,83 & 50 & 50 & 25 \\
\hline $\begin{array}{l}\text { LANTAI } 2 \\
\text { LVMDP KE SDP }\end{array}$ & 51,77813 & 84,139 & 25 & 25 & 16 \\
\hline $\begin{array}{l}\text { LANTAI } 3 \\
\text { LVMDP KE SDP } \\
\text { Penerangan }\end{array}$ & 7,868945 & 12,787 & 1,5 & 1,5 & 1,5 \\
\hline $\begin{array}{l}\text { Lapangan } \\
\text { LVMDP KE SDP }\end{array}$ & 427,9184 & 695,37 & 300 & 300 & 150 \\
\hline $\begin{array}{l}\text { Pompa } \\
\text { 1. SDP LANTAI } 1\end{array}$ & 86,60254 & 140,73 & 50 & & 25 \\
\hline PP/LP 1.1 & 18,42087 & 23,026 & 6 & 6 & 4 \\
\hline $\begin{array}{l}\text { PP/LP } 1.2 \\
\text { AIR CONDITIONER }\end{array}$ & 7,794229 & 9,7428 & 1,5 & 1,5 & 4 \\
\hline $\begin{array}{l}1.1 \\
\text { AIR CONDITIONER }\end{array}$ & 70,50466 & 88,131 & 25 & 25 & 16 \\
\hline $\begin{array}{l}\text { 1.2 } \\
\text { 2. SDP LANTAI } 2\end{array}$ & 16,40354 & 20,504 & 2,5 & 2,5 & 4 \\
\hline PP/LP 2.1 & 4,2656 & 5,332 & 1,5 & 1,5 & 4 \\
\hline $\begin{array}{l}\text { PP/LP } 2.2 \\
\text { AIR CONDITIONER }\end{array}$ & 6,384815 & 7,981 & 1,5 & 1,5 & 4 \\
\hline $\begin{array}{l}\text { 2.1 } \\
\text { 3. SDP LANTAI } 3 \\
\text { Penerangan + AC }\end{array}$ & 41,12772 & 51,41 & 10 & 10 & 10 \\
\hline $\begin{array}{l}\text { Lantai } 3 \\
\text { 4. SDP Penerangan } \\
\quad \text { Lapangan } \\
\text { Penerangan }\end{array}$ & 7,868945 & 9,8362 & 1,5 & 1,5 & 1,5 \\
\hline $\begin{array}{l}\text { Lapangan Tiang } 1 \\
\text { Penerangan }\end{array}$ & 106,9796 & 133,72 & 50 & 50 & 25 \\
\hline $\begin{array}{l}\text { Lapangan Tiang } 2 \\
\text { Penerangan }\end{array}$ & 106,9796 & 133,72 & 95 & 95 & 50 \\
\hline $\begin{array}{l}\text { Lapangan Tiang } 3 \\
\text { Penerangan }\end{array}$ & 106,9796 & 133,72 & 240 & 240 & 120 \\
\hline $\begin{array}{l}\text { Lapangan Tiang } 4 \\
\text { 5. SDP Pompa }\end{array}$ & 106,9796 & 133,72 & 95 & 95 & 50 \\
\hline Pompa Air Bersih 1 & 5,094267 & 6,3678 & 1,5 & & 4 \\
\hline Pompa Air Bersih 2 & 5,094267 & 6,3678 & 1,5 & & 6 \\
\hline Pompa Hydrant & 76,41401 & 95,518 & 25 & & 16 \\
\hline
\end{tabular}

Tabel 5. Perhitungan Manual Kabel

\subsubsection{Perhitungan Hubung Singkat}

Sebagai contoh, untuk menghitung arus hubung singkat pada PP/LP 1.2 terlebih dahulu harus mengetahui impedansi sisi upstream atas, trafo, konduktor antara trafo dan LVMDP, dan SDP Lantai 1

\section{Impedansi sisi Upstream}

Untuk mencari impedansi jaringan sisi atas dengan cara seperti berikut :

$$
\begin{aligned}
& Z_{Q}=\frac{1,1 \times 400 V^{2}}{500 M V A} \\
& Z_{Q}=\frac{176.000}{500.000} \quad=0,352 \mathrm{~m} \Omega
\end{aligned}
$$

Yang kemudian nilai resistansi dan reaktasi didapatkan menggunakan cara seperti berikut:

$$
\begin{aligned}
& X_{Q}=0,995 \times 0,352 \\
& R_{Q}=0,100 \times 0,350 \\
& X_{Q}=0,35024 \mathrm{~m} \Omega / \mathrm{m} \\
& R_{Q}=0,035024 \mathrm{~m} \Omega / \mathrm{m}
\end{aligned}
$$

\section{Impedansi Trafo}

Trafo yang digunakan pada Hotel Chanti Semarang sebesar 630kVA dengan tegangan hubung singkatnya sebesar $4 \%$ maka didapatkan impedansi trafonya dengan menggunakan cara seperti berikut :

$$
\begin{aligned}
& Z_{T}=\frac{420^{2}}{630} \cdot \frac{4}{100} \\
& Z_{T}=11,2 \mathrm{~m} \Omega / \mathrm{m}
\end{aligned}
$$

Dan nilai resistansi dan reaktasi trafo didapatkan dengan menggunakan cara sebagai berikut :

$$
\begin{gathered}
X_{Q}=0,95 \cdot Z_{T} \\
X_{Q}=10,64 \mathrm{~m} \Omega / \mathrm{m} \\
R_{Q}=0,31 \cdot Z_{T} \\
R_{Q}=3,472 \mathrm{~m} \Omega / \mathrm{m}
\end{gathered}
$$

\section{Arus Hubung Singkat Trafo ke LVMDP}

Dari Transformator ke Automatic Transfer Switch (ATS) (incoming) Menggunakan kabel $300 \mathrm{~mm} 2 \mathrm{Cu}$ dengan panjang 5 meter sedangkan dari ATS ke Low Voltage Gidtribution Panel (LVMDP) (outgoing) menggunakan $300 \mathrm{~mm} 2 \mathrm{Cu}$ dengan panjang 5 meter, sesuai dengan persamaan (2.18) dan (2.19) sehingga diperoleh resistansi dan reaktansi sebagai berikut :

Sisi incoming :

$$
R_{\text {incoming }}=\frac{22,21}{300} .5
$$




$$
\begin{gathered}
R_{\text {incoming }}=0,3683 \mathrm{~m} \Omega / \mathrm{m} \\
X_{\text {incoming }}=\frac{0,08}{1} \cdot 5 \\
X_{\text {incoming }}=0,4 \mathrm{~m} \Omega / \mathrm{m}
\end{gathered}
$$

Sisi outgoing :

$$
\begin{aligned}
R_{\text {incoming }} & =\frac{22,21}{300} \cdot 5 \\
R_{\text {incoming }}= & 0,3683 \mathrm{~m} \Omega / \mathrm{m} \\
X_{\text {incoming }} & =\frac{0,08}{1} \cdot 5 \\
X_{\text {incoming }} & =0,4 \mathrm{~m} \Omega / \mathrm{m}
\end{aligned}
$$

Arus Hubung Singkat dariLVMDP ke SDP Lantai 1 Dari LVMDP ke SDP Lantai 1 menggunakan $50 \mathrm{~mm} 2 \mathrm{Cu}$ dengan panjang 1 meter, sesuai dengan persamaan (2.18) dan (2.19) sehingga diperoleh resistansi dan reaktansi sebagai berikut :

$$
\begin{gathered}
R_{1 p h}=\frac{22,21}{50} \cdot 1 \\
R_{1 p h}=0,442 \mathrm{~m} \Omega / \mathrm{m} \\
X_{1 p h}=\frac{0,08}{1} \cdot 1 \\
X_{1 p h}=0,08 \mathrm{~m} \Omega / \mathrm{m}
\end{gathered}
$$

\section{Arus Hubung Singkat dari SDP Lantai 1 ke PP/LP}

\section{2}

Dari SDP Lantai 1 ke PP/LP 1.2 menggunakan $6 \mathrm{~mm} 2 \mathrm{Cu}$

\begin{tabular}{|c|c|c|c|c|}
\hline SUMBER & $\begin{array}{l}\text { Panjang } \\
\text { Kabel } \\
\text { (meter) }\end{array}$ & $\begin{array}{c}\text { Luas } \\
\text { Penamp } \\
\text { ang } \\
\text { Pengha } \\
\text { ntar } \\
\text { (mm2) }\end{array}$ & $\begin{array}{l}Z \text { total } \\
(\mathrm{m} \Omega)\end{array}$ & $\operatorname{ISC}(k A)$ \\
\hline KABEL & & & & \\
\hline $\begin{array}{l}\text { INCOMING } \\
\text { KABEL }\end{array}$ & 5 & $2 \times 300$ & 12,03146 & 21,0282 \\
\hline $\begin{array}{l}\text { OUTGOING } \\
\text { PANEL SDP }\end{array}$ & 5 & $2 \times 300$ & 12,53071 & 20,1904 \\
\hline MDP KE SDP & & & & \\
\hline $\begin{array}{l}\text { LANTAI } 1 \\
\text { MDP KE SDP }\end{array}$ & 1 & 50 & 12,76159 & 19,8251 \\
\hline $\begin{array}{l}\text { LANTAI } 2 \\
\text { MDP KE SDP }\end{array}$ & 5 & 25 & 14,95532 & 16,9171 \\
\hline $\begin{array}{l}\text { LANTAI } 3 \\
\text { MDP KE SDP } \\
\text { Penerangan }\end{array}$ & 10 & 1,5 & 152,099 & 1,66339 \\
\hline $\begin{array}{l}\text { Lapangan } \\
\text { MDP KE SDP }\end{array}$ & 60 & 300 & 18,71619 & 13,5177 \\
\hline $\begin{array}{l}\text { Pompa } \\
\text { 1. SDP LANTAI } 1\end{array}$ & 60 & 50 & 34,95198 & 7,2385 \\
\hline PP/LP 1.1 & 2 & 6 & 17,02898 & 14,857 \\
\hline $\begin{array}{l}\text { PP/LP } 1.2 \\
\text { AIR } \\
\text { CONDITIONER }\end{array}$ & 2 & 1,5 & 36,20926 & 6,98716 \\
\hline $\begin{array}{l}1.1 \\
\text { AIR } \\
\text { CONDITIONER }\end{array}$ & 2 & 25 & 13,65199 & 18,5321 \\
\hline $\begin{array}{l}1.2 \\
\text { 2. SDP LANTAI } 2\end{array}$ & 2 & 2,5 & 25,39588 & 9,96225 \\
\hline PP/LP 2.1 & 20 & 1,5 & 303,6437 & 0,83321 \\
\hline $\begin{array}{l}\text { PP/LP } 2.2 \\
\text { AIR } \\
\text { CONDITIONER }\end{array}$ & 2 & 1,5 & 40,08058 & 6,31228 \\
\hline $\begin{array}{l}2.1 \\
\text { 3. SDP LANTAI } 3 \\
\text { Penerangan + AC }\end{array}$ & 2 & 10 & 17,99198 & 14,0618 \\
\hline $\begin{array}{l}\text { Lantai } 3 \\
\text { 4. SDP } \\
\text { Penerangan } \\
\text { Lapangan }\end{array}$ & 10 & 1,5 & 152,099 & 1,66339 \\
\hline Penerangan & & & & \\
\hline $\begin{array}{l}\text { Lapangan Tiang } 1 \\
\text { Penerangan }\end{array}$ & 2 & 50 & 19,28027 & 13,1222 \\
\hline $\begin{array}{l}\text { Lapangan Tiang } 2 \\
\text { Penerangan }\end{array}$ & 70 & 95 & 33,38869 & 7,57742 \\
\hline $\begin{array}{l}\text { Lapangan Tiang } 3 \\
\text { Penerangan }\end{array}$ & 170 & 240 & 38,76608 & 6,52632 \\
\hline $\begin{array}{l}\text { Lapangan Tiang } 4 \\
\text { 5. SDP Pompa } \\
\text { Pompa Air Bersih }\end{array}$ & 70 & 95 & 33,38869 & 7,57742 \\
\hline $\begin{array}{l}1 \\
\text { Pompa Air Bersih }\end{array}$ & 2 & 1,5 & 62,51613 & 4,04696 \\
\hline 2 & 2 & 1,5 & 62,51613 & 4,04696 \\
\hline Pompa Hydrant & 20 & 25 & 51,74627 & 4,88924 \\
\hline
\end{tabular}
dengan panjang 2 meter, sesuai dengan persamaan (2.18) dan (2.19) sehingga diperoleh resistansi dan reaktansi sebagai berikut :

$$
\begin{gathered}
R_{1 p h}=\frac{22,21}{6} \cdot 2 \\
R_{1 p h}=7,366 \mathrm{~m} \Omega / \mathrm{m} \\
X_{1 p h}=\frac{0,08}{1} \cdot 2 \\
X_{1 p h}=0,16 \mathrm{~m} \Omega / \mathrm{m}
\end{gathered}
$$

Dengan cara yang sama maka diperoleh perhitungan hubung singkat sebagai berikut :

$$
\begin{gathered}
I_{s c}=\frac{c_{\max } \cdot U_{0}}{Z} \\
=\frac{1,1 \cdot 400}{\sqrt{3} \cdot \sqrt{(12,05236)^{2}+(12,03024)^{2}}} \\
I_{s c}=14,85703 \mathrm{kA}
\end{gathered}
$$

Dengan cara yang sama maka diperoleh data sebagai berikut :
Tabel 6. Perhitungan Arus Hubung Singkat

\subsection{Analisis}

\subsubsection{Perbandingan Luas Penampang Kabel}

Tabel 6. diatas menunjukan luas penampang penghantar sudah melalui penyesuaian terhadap jatuh tegangan agar tidak lebih dari $4 \%$ pada ujung beban. Terdapat perbedaan pada luas penampang hantar antara perhitungan manual dan hasil simulasi Ecodial dimana luas penampang penghantar Ecodial rata - rata lebih besar dibandingkan 
hasil perhitungan manual dengan rincian $64 \%$ lebih besar dan $36 \%$ sama besar. Hal ini dikarenakan pada hasil simulasi Ecodial juga memperhitungkan faktor harmonic sedangkan untuk perhitungan manual berdasarkan PUIL hanya memperhitungkan kuat hantar arus pada konduktor saja. $40 \%$ perbedaan nilai luas penampang pada ecodial dan perhitungan manual juga sudah menunjukan toleransi 1 tingkat pada rating kabelnya. Dan dari hasil keduanya sudah memenuhi standart.

Tabel 7. Perbandingan Luas Penampang Kabel Ecodial 4.8 Terhadap Perhitungan Manual

\begin{tabular}{|c|c|c|c|c|c|c|c|c|c|c|c|}
\hline \multirow{2}{*}{\multicolumn{8}{|c|}{ tena }} & \multirow{3}{*}{ Sumber } & \multirow{2}{*}{\multicolumn{2}{|c|}{$\operatorname{lsc}(\mathrm{kA})$}} & \multirow[b]{3}{*}{ Keterangan } \\
\hline & & & & & & & & & & & \\
\hline saja. 40 & o pert & edaan & 1lat luc & s pena & npang & pada e & odial. & & Manual & Ecodial & \\
\hline dan per & itunga & manu & 1 juga & udah r & ienunju & Kan tol & rans1 & TRAFO KE ATS & 21,028209 & 21,7 & lebih besar \\
\hline 1 tingk & pada & rating & abelny & a. Dan & dari ha & sil ked & lanya & $\begin{array}{l}\text { ATS KE LVMDP } \\
\text { PANEL SDP }\end{array}$ & 20,190398 & 21,4 & lebih besar \\
\hline \multirow{3}{*}{\multicolumn{8}{|c|}{$\begin{array}{l}\text { Tabel 7. Perbandingan Luas Penampang Kabel Ecodial } 4.8 \\
\text { Terhadap Perhitungan Manual }\end{array}$}} & LVMDP KE SDP & & & \\
\hline & & & & & & & & LANTAI 1 & 19,825109 & 21 & lebih besar \\
\hline & & & & & & & & LVMDP KE SDP & & 19,6 & \\
\hline \multirow{2}{*}{ SUMBER } & \multicolumn{2}{|c|}{ FASA $(\mathrm{mm} 2)$} & \multicolumn{2}{|c|}{ Netral (mm2) } & \multicolumn{2}{|c|}{$\mathrm{PE}(\mathrm{mm} 2)$} & \multirow{2}{*}{ Keterangan } & $\begin{array}{l}\text { LANIAI } 2 \\
\text { LVMDP KE SDP }\end{array}$ & 16,91/061 & & lebıh besar \\
\hline & Manual & Ecodial & Manual & Ecodial & Manual & Ecodial & & LANTAI 3 & & 6,05 & \\
\hline \multicolumn{8}{|l|}{ TRAFO KE } & $\begin{array}{l}\text { LAINIAI } 3 \\
\text { LVMDP KE SDP }\end{array}$ & 1,6633902 & & lebın besar \\
\hline $\begin{array}{l}\text { ATS } \\
\text { ATS KE }\end{array}$ & $2 \times 400$ & $3 \times 400$ & $2 \times 400$ & $3 \times 400$ & 300 & $2 \times 300$ & lebih besar & Penerangan & & 13,9 & \\
\hline \multirow{2}{*}{$\begin{array}{l}\text { LVMDP } \\
\text { PANEL SDP }\end{array}$} & $2 \times 300$ & $3 \times 300$ & $2 \times 300$ & $3 \times 300$ & 240 & $2 \times 240$ & lebih besar & Lapangan & 13,517712 & & lebih besar \\
\hline & & & & & & & & LVMDP KE SDP & & & \\
\hline LVMDP KE & & & & & & & & Pompa & 7,2385032 & 10 & lebih besar \\
\hline \multirow{2}{*}{$\begin{array}{l}\text { SDP LANTAI } 1 \\
\text { LVMDP KE }\end{array}$} & 50 & 50 & 50 & 50 & 25 & 25 & sama & 1. SDP LANTAI 1 & & & \\
\hline & & & & & & & & PP/LP 1.1 & 14,85703 & 18,4 & lebih besar \\
\hline $\begin{array}{l}\text { SDP LANTAI } 2 \\
\text { LVMDP KE }\end{array}$ & 25 & 50 & 25 & 50 & 16 & 25 & lebih besar & PP/LP 1.2 & 6,9871638 & 8,29 & lebih besar \\
\hline \multirow{3}{*}{$\begin{array}{l}\text { SDP LANTAI } 3 \\
\text { LVMDP KE } \\
\text { SDP }\end{array}$} & 1,5 & 2,5 & 1,5 & 2,5 & 1,5 & 4 & lebih besar & AIR & & & \\
\hline & & & & & & & & CONDITIONER & & 20,1 & \\
\hline & & & & & & & & 1.1 & 18,532098 & & lebih besar \\
\hline $\begin{array}{l}\text { SDP } \\
\text { Penerangan }\end{array}$ & & & & & & & & AIR & & & \\
\hline \multirow{2}{*}{$\begin{array}{l}\text { Lapangan } \\
\text { LVMDP KE }\end{array}$} & 300 & 300 & 300 & 300 & 150 & 150 & lebih besar & CONDITIONER & & 14,6 & \\
\hline & & 70 & & & & & & 1.2 & 9,9622453 & & lebih besar \\
\hline $\begin{array}{l}\text { SDP Pompa } \\
\text { 1. SDP LANTAI }\end{array}$ & 50 & 70 & & & 25 & 35 & lebih besar & 2. SDP LANTAI 2 & & & \\
\hline 1 & & & & & & & & PP/LP 2.1 & 0,8332135 & 1,01 & lebih besar \\
\hline PP/LP 1.1 & 6 & 10 & 6 & 10 & 4 & 10 & lebih besar & PP/LP 2.2 & 6,3122845 & 7,9 & lebih besar \\
\hline PP/LP 1.2 & 1,5 & 1,5 & 1,5 & 1,5 & 4 & 4 & sama & AIR & & & \\
\hline AIR & & & & & & & & CONDITIONER & & 18,5 & \\
\hline CONDITIONER & & & & & & & & 2.1 & 14,06182 & & lebih besar \\
\hline $\begin{array}{l}1.1 \\
\text { AIR }\end{array}$ & 25 & 35 & 25 & 50 & 16 & 25 & lebih besar & 3. SDP LANTAI 3 & & & \\
\hline CONDITIONER & & & & & & & & Penerangan + AC & & 6,05 & \\
\hline $\begin{array}{l}\text { 1.2 } \\
\text { 2. SDP LANTAI }\end{array}$ & 2,5 & 4 & 2,5 & 4 & 4 & 4 & lebih besar & $\begin{array}{l}\text { Lantai } 3 \\
\text { 4. SDP }\end{array}$ & 1,6633902 & & lebih besar \\
\hline 2 & & & & & & & & Penerangan & & & \\
\hline PP/LP 2.1 & 1,5 & 1,5 & 1,5 & 1,5 & 4 & 4 & sama & Lapangan & & & \\
\hline PP/LP 2.2 & 1,5 & 1,5 & 1,5 & 1,5 & 4 & 4 & sama & Penerangan & & & \\
\hline $\begin{array}{l}\text { AIR } \\
\text { CONDITIONFR }\end{array}$ & & & & & & & & Lapangan Tiang 1 & 13,122221 & 13,7 & lebih besar \\
\hline $\begin{array}{l}\text { CONDITIONER } \\
2.1\end{array}$ & 10 & 25 & 10 & 16 & 10 & 16 & lebih besar & Penerangan & & 82 & \\
\hline 3. SDP LANTAI & & & & & & & & Lapangan Tiang 2 & 7,5774165 & 8,2 & lebih besar \\
\hline 3 & & & & & & & & Penerangan & & 6,7 & \\
\hline Penerangan + & & & & & & & & Lapangan Tiang 3 & 6,5263244 & & lebih besar \\
\hline $\begin{array}{c}\text { AC Lantai } 3 \\
4 . S D P\end{array}$ & 1,5 & 2,5 & 1,5 & 2,5 & 1,5 & 4 & lebih besar & Penerangan & & 8.2 & \\
\hline $\begin{array}{c}\text { 4. SDP } \\
\text { Penerangan }\end{array}$ & & & & & & & & $\begin{array}{c}\text { Lapangan Tiang } 4 \\
\text { 5. SDP Pompa }\end{array}$ & 7,5774165 & 0,2 & lebih besar \\
\hline $\begin{array}{l}\text { Lapangan } \\
\text { Penerangan }\end{array}$ & & & & & & & & Pompa Air Bersih & & & \\
\hline $\begin{array}{l}\text { Penerangan } \\
\text { Lapangan }\end{array}$ & & & & & & & & & 4,0469556 & 5,41 & lebih besar \\
\hline Tiang 1 & 50 & 70 & 50 & 70 & 25 & 35 & lebih besar & Pompa Air Bersih & & 5,41 & \\
\hline Penerangan & & & & & & & & 2 & 4,0469556 & 0,41 & lebih besar \\
\hline Lapangan & 05 & 95 & 05 & 05 & & & & Pompa Hydrant & 4,8892417 & 7,24 & lebih besar \\
\hline
\end{tabular}

\subsubsection{Perbandingan Hubung Singkat}

Tabel 8. Perbandingan Hubung Singkat Ecodial 4.8 Terhadap Perhitungan Manual

Dapat dilihat juga dari Tabel 7 . bahwa $100 \%$ sama perbandingan arus hubung singkat ecodial lebih besar dari perhitungan manual dikarekanakan nilai luas sama penghantar ecodial memang rata-rata lebih besar dari perhitungan manual. Nilai hubung singkat tertinggi pada sama Ecodial sebesar 21,7 kA dan untuk manual 21,02 kA serta lebih besar untuk arus hubung singkat terendah pada Ecodial sebesar lebih besar 1,01 kA dan untuk manual sebesar 0,83 kA. Semua perbedaan angka pada ecodial dan manual memiliki toleransi rating 1 tingkat dan ini menunjukan bahwa program Ecodial 4.8 sudah memenuhi standart keamanan. 


\section{Kesimpulan}

Dari hasil analisis diatas, dapat disimpulkan bahwa besarnya daya sumber yang digunakan untuk menyuplai Stadion Citarum Semarang menurut Ecodial 4.8 sebesar 404632 VA yang menggunakan trafo sebesar $630 \mathrm{kVA}$ untuk menyuplai serta menggunakan sistem grounding TN-S Pada pemilihan kabel, $40 \%$ perbedaan pemilihan kabel pada Ecodial 4.8 ini memiliki nilai toleransi \pm 1 tingkat untuk rating kabelnya. Dan dari hasil keduanya sudah memenuhi standart. Pada Ecodial 4.8 nilai reaktansi kabel $\leq 50 \mathrm{~mm}^{2}$ diabaikan yang mempengaruhi perbedaan besarnya nilai arus hubung singkat dan drop voltage. Pada arus hubung singkat antara Ecodial 4.8 dan perhitungan manual memiliki nilai toleransi perbedaan rating \pm 1 tingkat dengan nilai perbedaan tersebut $\pm 1 \%$. Pada kalkulasi Ecodial 4.8 menggunakan standar IEC yang sesuai dengan PUIL 2011 yang dipakai di Indonesia ,Sehingga proyek perencanaan instalasi ini dapat segera direalisasikan dan dibangun.

\section{Referensi}

[1]. P.Van Harten , Ir.E.Setiawan . 1981 . Instalasi Listrik Arus Kuat 1 . Indonesia.

[2]. P.Van Harten , Ir.E.Setiawan . 1981 . Instalasi Listrik Arus Kuat 2 . Indonesia.

[3]. Persyaratan Umum Instalasi Listrik 2011. Jakarta : Badan Standarisasi Nasional, 2011.

[4]. SIEMENS. Innovative Power Distribution in Sports Arena..2012.

[5]. CENELEC. Brussels : European Committee for Electrotechnical Standardization.2011.
[6]. SPLN 1"1995, Tegangan Standar PLN

[7]. Peraturan Menteri Energi dan Sumber Daya Mineral Nomor 27 Tahun 2017, Tingkat Mutu Pelayanan dan Biaya yang Terkait dengan Penyaluran Tenaga Listrik Oleh PT PLN (PERSERO).

[8]. IEC 60228.2004: Conductors of Insulated Cables.

[9]. PT Trafindo Prima Perkasa : Product Catalogue Oil Immersed Transformers.

[10]. Ismansyah, "Perancangan Instalasi Listrik Pada Rumah Dengan Daya Lisrrik Besar", Univ. Indonesia Depok, 2009.

[11]. Mario Abednego, "Analisa Dan Perancangan Audit Energi Pada Sistem Kelistrikan Hotel Ciputra Semarang", Universitas Diponegoro, 2012.

[12]. M.Hasan, "Studi Kelayakan Instalasi Penerangan Rumah Di Atas Umur 15 Tahun Terhadap Puil 2000 Di Desa Pancur Kecamatan Pancur Kabupaten Rembang", Jurnal Teknik Elektro, vol.5 no.1,2013.

[13]. A.Chenny, "Perancangan Kelistrikan Pada Kondotel Borobudur Blimbing Kota Malang", Universitas Brawijaya, 2014.

[14]. I. Santoso, "Perancangan Instalasi Listrik Pada Blok Pasar Modern Dan Apartemen Di Gedung Kawasan Pasar Terpadu Blimbing Malang", Universitas Brawijaya, 2014.

[15]. Nurfitri, "Studi Perancangan Instalasi Listrik Pada Gedung Bertingkat Onih Bogor", Universitas Pakuan, 2015.

[16]. Atmam, D. Meliala, "Analisis Sistem Kelistrikan Di Universitas Lancang Kuning Pekanbaru Dengan Menggunakan Electric Transient And Analysis Program (ETAP)", 2015.

[17]. M. Zulkaromi, "Perancangan Instalasi Listrik Pasar Klewer Surakarta Menggunakan Software SIMARIS", Universitas Diponegoro, 2017. 